\section{Demchenko V., Trubachev A., Hron 5.}

\title{
COMPARATIVE ANALYSIS OF THE EFFICIENCY OF GAS BOILERS BY EXPRESS METHOD OF MULTI-CRITERIA ASSESSMENT
}

Об'єктом дослідження є метод експрес-аналізу багатокритерійної оиінки, на прикладі порівняння ефективності побутових газових котлів типу АОГВ (апарат опалювальний газовий водонагрівний). На даний час на українському ринку пропонується велика кількість газових котлів украйнських та зарубіжних заводів-виробників, яка має незначні відмінності. Це обумовлено в першу чергу простотою конструктивного рімення газових котлів даної моделі та використанням для них однакових пальникових пристроїв і блоків автоматики італійського виробництва.

Порівняння показників ефективності даного виду продукції є великою проблемою. Існуючі методики розрахунку показників ефективності та чинні нормативні документи не завжди дають коректне уявлення про якість продукиії. Тому в даній роботі пропонується новий метод експрес-аналізу порівняння ефективності, який дозволяє в короткий час провести коректне порівняння показників роботи котельного обладнання без використання великої кількості розрахунків, які потребують більших затрат часу. Ця проблема вирішується вибором трвох якірних критерї̈в ефективності, а саме енергетичного, екологічного та економічного, з подальшим визначенням довірчих інтервалів кожного з показників та побудові на їх базі трикритеріальної діаграми. Даний метод дозволяє наочно бачити недоліки та переваги кожного з котлів, планувати заходи по їх модернізації та визначати їх рейтинг.

В ході дослідження використовувалися матеріали технічного звіту теплоекологічних іспитів семи газових котлів, який було проведено загальноприйнятою методикою. Аналіз отриманих результатів було проведено методом сум з подальшим ранжуванням афектів та подальшою верифікацією запропонованого експрес-методу порівняння ефективності. Отриманий якісний результат дозволяє зробити висновок, що запропонований експрес-метод більш детально та коректно, ніж інші відомі методи аналізу визначає рейтингове положення кожного котла. Це дозволить потенційному інвестору зробити правильний висновок при заміні та придбанні нового котельного обладнання. Використання методу експрес-аналізу дає змогу заводам-виробникам котельного обладнання провести реальну оцінку якості продукцї та визначити шляхи по подоланню ї недоліків.

Ключові слова: газовий котел, ефективність енергетичного обладнання, системний аналіз, ваговий коефіиієнт.

\section{Introduction}

Heat supply systems have significant potential for energy savings. The total potential of energy efficiency in Ukraine is about $45 \%$ of the volume of consumed fuel and energy resources. The daily energy losses in Ukraine are about 3.5 million USD. All this negatively affects the national economy of the country. Reasonable and efficient energy consumption is a key factor in creating new jobs and economic growth in the country.

Energy saving in the field of natural gas consumption remains the most critical. Ukraine consumes about 40.0 billion $\mathrm{m}^{3}$ of natural gas per year, of which:

- 13.0 billion $\mathrm{m}^{3}$ consumes industry;

- 4.0 billion $\mathrm{m}^{3}$ are technical needs and losses during transportation;

- 5.0 billion $\mathrm{m}^{3}$ is spent on cooking and power generation;

- 17.8 billion $\mathrm{m}^{3}$ for heating of apartment and private houses.

At the same time, the level of unproductive gas consumption losses is from 30 to $40 \%$. By reducing them to the European level, it is possible to save up to 9.0 billion $\mathrm{m}^{3}$ of natural gas per year.

About 11.0 billion $\mathrm{m}^{3}$ of gas is consumed per year for heating homes, while the potential for energy saving reaches 6.3 billion $\mathrm{m}^{3}$, of which 1.7 billion $\mathrm{m}^{3}$ are used for heating and hot water by household gas boilers. $60 \%$ of heating boilers, which are sold in Ukraine, are occupied by imported boilers. Currently, $40 \%$ of the market needs are covered by domestic-made boilers. One of the models, which are mass-produced and mass-sold for many years, is floor boilers of the WHGA type (water heating gas apparatus) operating on gas. Therefore, the appropriate solution for energy efficiency is ensuring the quality of boilers at the design, manufacturing and operation stages, as well as to develop recommendations for their modernization.

When choosing boiler equipment, it is desirable to be guided by objective methods of system analysis and multicriteria evaluation of efficiency indicators. Existing benchmarking methods do not provide systemic estimates. Therefore, it is urgent to improve the methods of multi-criteria evaluation of the effectiveness of heating boilers, first of all, by technological, economic and environmental conditions. 


\section{The object of research and its technological audit}

The object of research is a method of rapid analysis of multi-criteria evaluation using the example of comparing the efficiency of domestic gas water boilers of the WHGA type; they have been used for many years for heating and supplying hot water to private houses and public utility facilities.

At the first stage, let's analyze and compare technical, environmental and economic indicators of models of domestic WHGA-type boilers designed for heating houses with a total area of about $100 \mathrm{~m}^{2}$, their characteristic features, which the manufacturing plants declare are:

- atmospheric burners;

- possibility of use in gravitational heating systems, without connecting to the mains;

- reduced water circulation in the heating system;

- efficiency - about $90 \%$, which is achieved by ex-

panding the heat exchange area and a small amount of water in the boiler;

- painting with anticorrosive enamels;

silent work and low cost.

The negative features of these models of boilers include:

- outdated technological solution to build a boiler;

- limited service life;

- short warranty period;

- sensitive response and impact on the boiler opera-

tion changes in the discharge in the chimney;

- decrease in productivity to a complete stop of the boiler operation under reduced gas pressure, and the like. For research, water boilers with a thermal capacity of about $12.0 \mathrm{~kW}$ [1] were provided:

- Ukrainian production, trademarks - ATEM «Zhytomyr 3» КСГ 012 CH; ATON АОГВM-12 EM; Danko Danko 12-CP; Termobar КC-Г-12,5;

- Russian production - ДS LEMAKS Premium 12,5; Siberia 2210-012 perf. 3 Siberia 11 and MIMAKS КСГ-12,5.

The investigated boilers are certified in Ukraine and declare an efficiency of $81 \div 93 \%$ with complete combustion of fuel. The boilers are equipped with automatic ignition and protection systems, ensuring their operation without permanent attendants.

According to the research program, the technical documentation for each boiler was reviewed. Regime-adjustment studies and complex - warm-heat tests were carried out on two main modes of operation of boilers with a minimum and maximum heat load at a vacuum of $3.5 ; 7.0$ and $15.0 \mathrm{~Pa}$, respectively. All the boilers were carried out on three main balance sheet experiments after determining the optimal coefficients of excess air with the lowest emissions of toxic components.

Operational tests were carried out at optimal values of the air excess factor, while the gas consumption and other necessary parameters were recorded. When conducting routine and balance tests, gas analysis and measurements of the temperature of combustion products were carried out in the flue duct behind the boiler (Fig. 1).

During the work, the conditions for reliable and economical operation of the boilers were found, the efficiency factors and other technical and economic indicators of the equipment operation were determined. Experiments to determine the content of nitrogen oxides and carbon in the combustion products, the influence of regime factors on the efficiency and the amount of emissions are conducted. When determining the gross boiler efficiency, the reverse balance method was used [2]. Measurements of the composition of the exhaust gases, their temperature and air temperature before the burner were carried out by a computer gas analyzer without interruption throughout the test. Recording of gas meter readings and other instruments was carried out every 10 minutes. Measurements and calculations of $\mathrm{CO}, \mathrm{NO}_{x}$ and other pollutants were carried out according to [3-5]. The thermal characteristics of the thermal insulation of the boiler elements were determined by analyzing the results obtained from thermograms (measurements with a thermal imager) and in hard-to-reach places with a pyrometer.

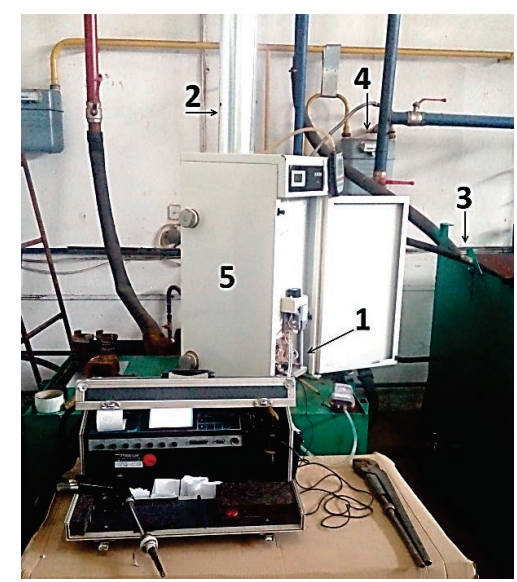

Fig. 1. Diagram of measurements of the parameters of the boiler: 1 - аir temperature and pressure; 2 - temperature, гarefaction and chemical composition of flue gases; 3 - flow rate and temperature of the coolant in the direct and return pipelines; 4 - flow, temperature and pressure of natural gas; 5 - boiler body temperature

The maximum achieved heat output for each of the boilers was about $12 \mathrm{~kW}$. The efficiency at the maximum achieved load was from 81 to $93.4 \%$, which is primarily due to the one-way flow of the coolant, using only the convective type of heat transfer and other operating characteristics of the equipment. The atmospheric lowpressure burners installed in the boilers operated reliably in research ranges of loads and air excess factors. Based on the carried out tests, calculations of the operation of boilers, certain economic, environmental and energy efficiency indicators, and proposed measures aimed at improving the efficiency and reliability of boilers operation is developed. The obtained data is illustrated by the summary Table 1, in which the color points of scores for each criterion for each boiler.

Table 1 clearly shows that all the studied models have almost identical indicators. All manufacturers' passport data of the boiler declare efficiency of at least $90 \%$.

However, the calculations carried out show that only boilers of the ATEM brand have this indicator at the level of $90-92 \%$, depending on the mode and conditions of operation.

The greatest heat output during full-scale tests was shown by the boiler produced by ATEM, the worst efficiencyof the MIMAKS boiler. 
Summary list of the main indicators of boilers

\begin{tabular}{|c|c|c|c|c|c|c|c|c|}
\hline \multirow[b]{2}{*}{ No. } & \multirow{2}{*}{$\begin{array}{c}\text { Parameter } \\
\text { name and unit }\end{array}$} & \multicolumn{7}{|c|}{ Bailer } \\
\hline & & $\begin{array}{c}\text { ATON } \\
\text { АОГВM-12 EM }\end{array}$ & $\begin{array}{c}\text { LEMAKS } \\
\text { Premium 12,5 }\end{array}$ & $\begin{array}{c}\text { ATEM Zhytomyг } 3 \\
\text { КСГО12СН }\end{array}$ & $\begin{array}{c}\text { Siberia } 2210012 \\
\text { perf. } 3\end{array}$ & $\begin{array}{c}\text { Danko } \\
\text { Danko-12 СР }\end{array}$ & $\begin{array}{c}\text { Termobar } \\
\text { КС--Г-12,5 ДБ }\end{array}$ & $\begin{array}{l}\text { MIMAK5 } \\
\text { КСГ-12,5 }\end{array}$ \\
\hline \multirow{2}{*}{1} & \multirow{2}{*}{$\begin{array}{l}\text { Perfor- } \\
\text { mance, \% }\end{array}$} & $88.31-81.33$ & $81.2-75.5$ & $92.18-90.82$ & $86.7-74.0$ & $86.3-73.81$ & $88.2-84.0$ & $84.6-72.05$ \\
\hline & & 3 & 5 & 1 & 4 & 4 & 2 & 6 \\
\hline \multirow{2}{*}{2} & \multirow{2}{*}{$\begin{array}{l}\text { Fuel utilization } \\
\text { factor, } \mathrm{m}^{3} / \mathrm{Gcal}\end{array}$} & 162.36 & 161.28 & 147.60 & 159.69 & 154.80 & 164.88 & 163.08 \\
\hline & & 5 & 4 & 1 & 3 & 2 & 7 & 6 \\
\hline \multirow{2}{*}{3} & \multirow{2}{*}{$\begin{array}{l}\text { Metal capacity, } \\
\mathrm{kg} / \mathrm{kW}\end{array}$} & 3.6 & 4.4 & 3.92 & 4.4 & 4.3 & 3.64 & 3.7 \\
\hline & & 1 & 6 & 4 & 6 & 5 & 2 & 3 \\
\hline \multirow{2}{*}{4} & \multirow{2}{*}{$\begin{array}{l}\text { Reduced cost, } \\
\text { USD/kW }\end{array}$} & 6.24 & 5.67 & 5.15 & 6.33 & 4.22 & 4.66 & 3.27 \\
\hline & & 6 & 5 & 4 & 7 & 2 & 3 & 1 \\
\hline \multirow{2}{*}{5} & Sum & 15 & 20 & 10 & 20 & 15 & 14 & 16 \\
\hline & Assessed score & 3 & 5 & 1 & 5 & 3 & 2 & 4 \\
\hline
\end{tabular}

Thermal imaging studies of heat losses through the boiler body showed that in all boilers there is a local overheating of the body, which exceeds permissible standards. Most of the overheating is noted in the Danko and MIMAKS boilers up to $120{ }^{\circ} \mathrm{C}$ in other boiler data, the temperature of the hull, in some areas ranges from 50 to $70{ }^{\circ} \mathrm{C}$.

It is important to note that all boilers, with the exception of the boiler of the MIMAKS trademark, are equipped with the same atmospheric burners with the automatic control and safety unit of the Italian company SIT. Thus, the costs and conditions of combustion of natural gas in them differ only because of the design features of the combustion chamber, the boiler aerodynamics and the convective heat exchanger.

Aerodynamic parameters of compared boilers showed a general tendency to decrease in efficiency from an increase in the aerodynamic resistance of the chimney. Conducted field tests showed that the boiler of the ATON brand was least susceptible to these changes in various operating modes, which is explained by its constructive solution. The worst efficiencywhen changing the aerodynamic mode of operation is in the boilers Siberia, Danko and MIMAKS.

All boilers have the same technological scheme, design and overall dimensions, and therefore the metal capacity of the boilers is about $4 \mathrm{~kg} / \mathrm{kW}$, although at the boiler АОГВМ-12 EM of ATON it is better than this indicator $-3.6 \mathrm{~kg} / \mathrm{kW}$.

An important environmental indicator is the temperature of flue gases, emissions of $\mathrm{CO}$ and nitrogen oxides, as well as reduction of carbon $\left(\mathrm{CO}_{2}\right)$.

According to these indicators, the emission of harmful substances is the most, at different modes, found in the ATON boiler, and the worst indicators in the LEMAKS, Siberia and MIMAKS boilers.

The present cost of the boilers in US dollars $/ \mathrm{kW}$ varies from 3 to 6 US dollars per kilowatt. The boilers of the Siberia trademark have the highest value, while the lowest cost of the boiler of the MIMAKS trademark is obviously explained by the use of a simple burner, without electronic ignition, and a control and safety unit of its own production.

The obtained data allow an expert assessment of the investigated boilers by quality indicators. When analyzing the operation of boilers, it is also necessary to take into account heat losses that are not subject to an exact analytical solution, however they affect the overall efficiencyindicators of the heat generation system.
These include:

- a change in the temperature of the feed water by $1{ }^{\circ} \mathrm{C}$ leads to an increase or decrease in the total heat consumption produced by the boiler by $1 \%$;

- with an increase in heat output of the boiler, the specific losses to the environment $q_{5}$ decrease, and the specific losses with exhaust gases $q_{2}$, chemical $q_{3}$ and mechanical $q_{4}$ do not increase significantly. At first, the $q_{5}$ loss reduction causes more $q_{2}+q_{3}+q_{4}$ losses and the boiler efficiency increases, but then $q_{2}+q_{3}+q_{4}$ losses grow faster than the $q_{5}$ reduction and the efficiency starts to decrease;

- if know the dependence of the boiler efficiency on heat load, it is possible to establish the loss of fuel during the boiler underload in the mode of reduced gas pressure and rational mode of its operation;

- heat loss by heated surfaces into the environment can be significant. For example, a wall with a temperature of $150{ }^{\circ} \mathrm{C}$ at an ambient temperature of $25{ }^{\circ} \mathrm{C}$ per $1920 \mathrm{kkal} /$ hour is lost from $1 \mathrm{~m}^{2}$. As a result of heat losses, the parameters of the coolant are reduced; - an excess of $0.2 \%$ increase in the coefficient of excess air increases the heat loss with exhaust gases by $1-2 \%$, the efficiency of the boiler is reduced by $2 \%$, the loss of fuel increases by $2.5-3 \%$;

- violation of the thermal insulation of the boiler by $30 \%$ or more leads to excess heat loss by $1-2 \%$; - an increase in the volume of products of combustion of fuel by $80-90 \%$ due to their dilution with air, increases the heat loss from chemical incomplete combustion of fuel by 2 times;

- the deviation of $\mathrm{CO}_{2}$ in the exhaust gases from the optimal value by $1 \%$ increases the fuel consumption of the boiler by $0.6 \%$;

- the presence of scale on the inner surface of the boiler with a thickness of $1.0 \mathrm{~mm}$ increases fuel consumption by $2 \%$;

- deviation of the boiler load from the optimum by $10 \%$ in the downward direction leads to fuel waste by $0.2 \%$, and in the upward direction - by $0.5 \%$.

It is clearly seen that the evaluation of effectiveness is a multicriteria task.

Summation of points in Table 1 shows that the ATEM boiler has the best performance, the worst characteristics in $\mathrm{Si}$ beria and LEMAKS boilers, which scored 20 points each. 
To determine the direction of further search for optimal solutions for comparing the investigated boilers, one can use evaluation methods based on the mathematical statistics apparatus.

\section{The aim and objectives of research}

The aim of research is development and test of a rapid method for system analysis of multi-criteria evaluation, with a specific example of determining the effectiveness of gas water boilers from seven manufacturing plants.

To achieve this aim it is necessary to perform the following tasks:

1. To carry out a detailed analysis of seven gas boilers on the Ukrainian market and, on the basis of the made measurements, calculate the efficiency, specific fuel consumption and emissions of harmful substances into the atmosphere.

2. To compare technological, environmental and economic indicators of boilers using well-known methods of mathematical statistics and methods of mathematical modeling and verify the rapid method for the analysis of multi-criteria evaluation.

\section{Research of existing solutions of the problem}

The concept of efficiency plays an important role in evaluating virtually any project. The theory and methods of optimization have been widely used to solve many problems in various fields of human activity. The properties and methods for finding optimal solutions to such problems are well studied both from theoretical and applied points of view [6, 7], but they do not consider the possibility of multi-criteria evaluation using the graph-analytical method. The work [8] is devoted to the analysis and planning of decisions in the economy; however, the question of combining and comparing economic indicators with technological and environmental ones remains unresolved. A multi-criteria evaluation of measures to optimize the consumption of heat energy is proposed in [9], but environmental problems are ignored. With all the importance in everyday practice, the concept of efficiency becomes quite a difficult and poorly formalized task.

One of such methods is the functioning environment analysis (FEA) [10,11]. FEA technology considers a complex object characterized by many input and output parameters. This technology is based on the fundamental principles of mathematical economics and actively uses modern achievements in the field of systems analysis and operations research [12].

FEA technology is a mathematical model that does not require the task of constants, the choice of distribution functions and other characteristics. However, the interpretation and analysis of the simulation results using the FEA technology presents a certain complexity, since it is practically impossible to imagine the behavior of an object in the multidimensional space of input and output parameters [13]. In addition, the standard analysis of the FEA technology, usually gives two ways to improve efficiency.

The method of multi-criteria analysis (MCI) is a mathematical tool of a systematic approach to complex decisionmaking problems [14]. Formation of the structure of the decision-making model in the MCI is quite a laborious process. However, as a result, it is possible to get a de- tailed idea of how the factors influencing the decisions and ratings that reflect the importance of the factors interact [15]. MCI does not have a means to validate data. This is an important drawback, which partially limits the possibilities of applying the method. MCI may be overly time consuming to make simple decisions because a large number of comparisons are required to collect data [16]. There are specialized software products For computer support of MCI.

Thus, the results of the analysis of literary sources allow to conclude that all existing methods have certain disadvantages and require the development of new rapid methods for quick analysis and evaluation of criteria for making strategic decisions.

\section{Methods of research}

The decision-making process in various fields of activity is in many respects similar. Application of the system analysis methodology when comparing the main indicators of boiler equipment allows developing measures to improve the efficiency of its use indicators. The main areas of application of the system methodology are the assessment of heat engineering (technological), economic and environmental efficiencyof equipment and making decisions on further modernization and optimization of the design of boilers.

To do this, use the method of comparison - the most common method of system analysis.

As can be seen from Table 1, the sum method was originally used, based on summing the values of certain indicators for each boiler. According to the results of a comparative comprehensive assessment, it is possible to decide which of the boilers should be considered the best for a number of specific features. Ranking indicators in descending order, the rating of WHGA-type boilers was established. The disadvantages of this method include the fact that the total of all indicators, the low results of individual indicators are covered by the high results of other indicators. In order to obtain an objective assessment, it is necessary to exclude those indicators that are most likely to affect the final result.

In order to obtain an objective assessment at the second stage of the study, the method of scoring was used, which is based on assigning ordinal values to boilers in accordance with the specified numerical categories. The scoring method consists in summing up the scores assigned to each indicator. The higher the score, the lower the score. The lower the score, the higher the rating of the object. The disadvantages of this method include the fact that, in fact, the difference in efficiencycan be very significant, or, conversely, purely nominal, which can vary significantly and distort the assessment. The need to apply the scoring method arose due to the fact that it is necessary to compare the effectiveness of seven boilers by four indicators.

This disadvantage is eliminated by using the interpolation method in the range of $1-7$ points.

At the third stage of the study, the 3E grapho-analytical method was used for a multi-criteria evaluation of decisionmaking efficiency $[17,18]$. It is based on a multi-criteria method of system analysis, which includes a wide range of mathematical and statistical methods and can be used for any calculations for making decisions in any field of 
activity. Multi-criteria analysis requires combining three different types of information in a single method that can be applied in practice. This method has practically no analogues and is based on making pair comparisons. Application of the «3E» method is completely independent of the sphere of activity in which a strategic decision is made. Therefore, the «3E» method is universal, and its application allows you to organize a decision support system.

The proposed method allows to obtain a graphic image of the result of a comparative analysis of the efficiency of WHGA-type boilers and with a high degree of probability to determine the rating of the products of manufacturers.

The analysis is based on three main criteria, namely, energy, environmental and economic. The results of the express analysis are graphically represented in the form of the area of allowable values in the triangular diagram $\ll 3 \mathrm{E}$ triangle» from the initial letters of the words.

An important factor in the calculations using the new «3E» method of rapid analysis is the identification of a confidence interval. Based on the expert assessment, it is proposed to assign the limits of confidence intervals, with a given reliability, for each criterion weight coefficient $K E$, which are dimensionless values expressed as a percentage. The intersection of the boundaries of the minimum values of weight coefficients forms confidence of WHGA-type boilers are defined, which are discussed in the next section of this paper.

An equilateral triangle is used to find the relationship between the weight indicators of equipment efficiency, diagonals in any level. From the vertices of the triangle lay the values obtained by calculation or in-situ measurement. The obtained benchmarks for the indicators of each boiler are combined, and at the intersection of the diagonals of the resulting small triangle, the basic rating of the boiler is obtained for three weights.

Formulas for calculating the weight coefficients are given in Table 2 . field (shaded area) of the $3 \mathrm{E}$ diagram, in which the ranks

The confidence interval of the $K E_{1}$ energy index is taken from $70 \%$ to $100 \%$ and the well-known formulas for calculating the efficiency of the boiler [2] are used to calculate it.

Actual values of the carbon dioxide content $\mathrm{CO}_{2}$ are taken as the weighting ecological index $K E_{2}$, which is calculated for each of the boilers in accordance with the current methods [3-5]. $\mathrm{CO}_{2}$ is selected as the main component, as it reflects the quality of the combustion of natural gas. This is justified by the fact that the maximum $\mathrm{CO}_{2}$ content in the analysis of the fuel is directly proportional to the fuel component and inversely proportional to the amount of harmful emissions and ballast gases in the combustion products. On this basis, $\mathrm{CO}_{2}$ values fully reflect the environmental efficiencyof fuel combustion. The confidence interval of the ecological coefficient $K E_{2}$ is proposed to be taken in the value from $5 \%$ to $10 \%$.

The confidence interval of the economic index $K E_{3}$ takes values from 60 to $100 \%$ and for its calculation the well-known formulas for calculating the fuel utilization factor (CFU) [2] are used. The calculated data on the consumption of natural gas for the production of $1.0 \mathrm{Gcal}$ of heat were converted into reference fuel. Then, using the [19] method and the [20] instruction, the interpolation method (Fig. 2) was used to recalculate the values for determining heat production by the corresponding fuel consumption in the range from 60 to $100 \%$ of possible values in accordance with the heat generation efficiency. After that, the CFU was determined in percent using the results obtained from the calculations. To build a confidence field $\ll 3 \mathrm{E}$ triangle» the resulting values of instrumentation need to be postponed in the reverse order.

The choice of the optimal variant of the boiler can be carried out using the attractiveness index, which is calculated by summing up the weighting indexes of the $K E$. Comparison and determination of deviations for each boiler from the target value of the standard is obtained by multiplying the values of the weighting indexes, as a result of which a proportionality index is obtained.

Thus, the proposed system for

Table 2 assessing the effectiveness allows determining the generalized inte-

The calculation of the weights for the construction of «3E triangle»

\begin{tabular}{|c|c|c|}
\hline Name & Formula for calculation & Confidence interval \\
\hline $\begin{array}{l}\text { Weight power } \\
\text { index } K E_{1}\end{array}$ & $\begin{array}{l}K E_{1}=100-\sum q_{i} \%, \\
\text { where } q_{i}-\text { heat losses, \% }\end{array}$ & 70-100\% \\
\hline $\begin{array}{l}\text { Weight eco- } \\
\text { logical index } \\
K E_{2}\end{array}$ & $\begin{array}{l}K E_{2}=\frac{\left(\mathrm{CO}_{2}+\mathrm{CO}+\mathrm{CH}_{4}+\sum n \cdot \mathrm{C}_{n} \mathrm{H}_{m}\right) \cdot 100}{\left(\mathrm{CO}_{2}+\mathrm{CO}+\mathrm{CH}_{4}+\sum n \cdot \mathrm{C}_{n} \mathrm{H}_{m}+\mathrm{N}_{2}+79 \cdot V^{0}\right)} \% \text {, } \\
\text { where } \mathrm{C}_{n} \mathrm{H}_{m}-\text { hydrocarbons included in the composition of } \\
\text { the gas, for example, methane } \mathrm{CH}_{4}(n=1, m=4) \text {, ethane } \mathrm{C}_{2} \mathrm{H}_{6} \\
(n=2, m=6) \text {, etc.; } V^{0}-\text { theoretical volume of dry air required } \\
\text { for complete combustion of fuel, } \mathrm{m}^{3} / \mathrm{kg}\end{array}$ & $5-10 \%$ \\
\hline $\begin{array}{l}\text { Weight eco- } \\
\text { nomic index } \\
K E_{3}\end{array}$ & $\begin{array}{l}K E_{3}=\left(1-\frac{B}{Q_{i}}\right) \%, \\
\text { where } B \text { - the total fuel consumption for the boiler unit, } \mathrm{kg} / \mathrm{h} \text {; } \\
\square_{i}-\text { specific heat of combustion, Gcal } / \mathrm{kg}\end{array}$ & 60-100 \% \\
\hline $\begin{array}{l}\text { Attractiveness } \\
\text { index } I^{p}\end{array}$ & $I^{p}=K E_{1}+K E_{2}+K E_{3}$ & $\begin{array}{l}\text { Integrated quantita } \\
\text { tive quality score }\end{array}$ \\
\hline $\begin{array}{l}\text { Proportionality } \\
\text { index } I^{a}\end{array}$ & $I^{a}=K E_{1} \cdot K E_{2} \cdot K E_{3}$ & $\begin{array}{l}\text { Integrated rate of } \\
\text { deviation from the } \\
\text { standard }\end{array}$ \\
\hline
\end{tabular}
gral indicators of each boiler, on the basis of which it is possible to judge their effectiveness with a sufficient degree of objectivity. The results of the integrated assessment, as well as a graphic illustration of the effectiveness, make it possible to identify the functioning deficiencies and develop measures to focus efforts on eliminating the deficiencies (Fig. 3, 4).

As can be seen from Fig. 3, 4, the boilers of the trademarks Lemax and MIMAKS are characterized by high fuel consumption and low efficiency, the best efficiency has the boiler company ATEM. The best environmental efficiency in case of negative pressure behind the boiler is $\Delta P=3.5 \mathrm{~Pa}$ at the rated power in the boilers of the ATEM and MIMAKS trademarks, the worst in the Данко, ATON and Termobar boilers. 


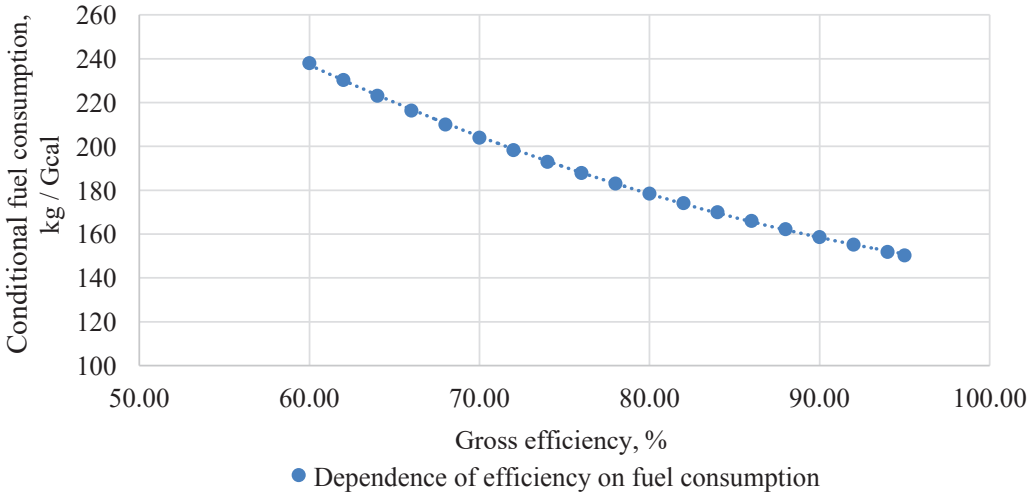

Fig. 2. Correlation field of theoretical data pairs according to the Instruction [20]

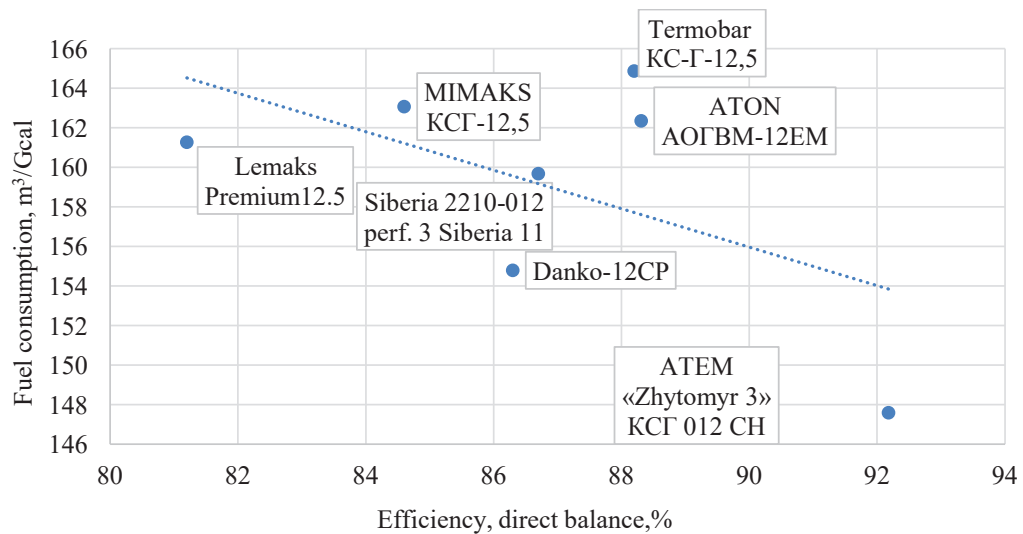

Fig. 3. Correlation field according to calculations of efficiency and fuel utilization factor

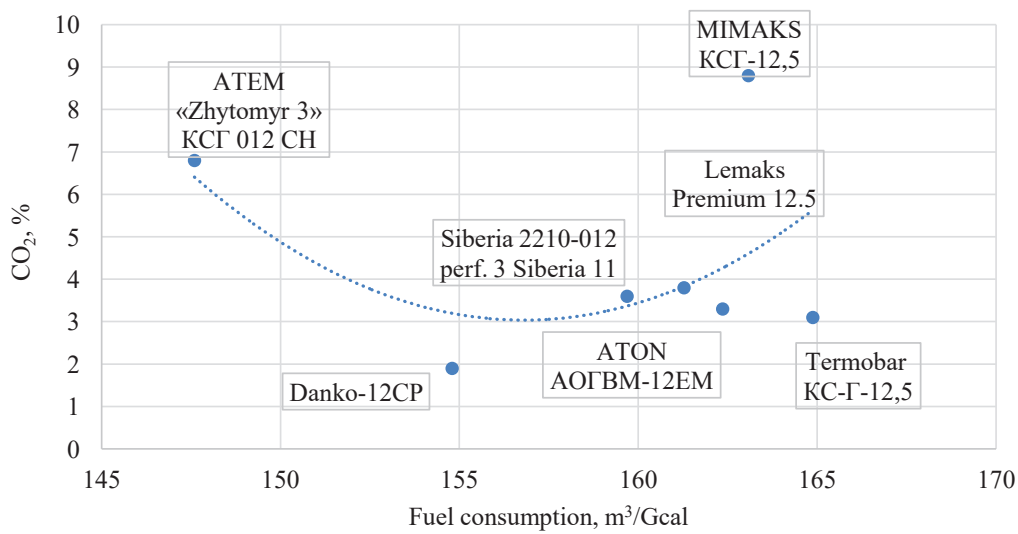

Fig. 4. Correlation field of data pairs: fuel utilization factor, $\mathrm{m}^{3} / \mathrm{Gcal}$ and $\mathrm{CD}_{2}$ \% at vacuum pressure behind the boiler $\Delta P=3.5 \mathrm{~Pa}$ at nominal power

\section{Research results}

The study was conducted according to the traditional method and the subsequent testing of the «3E» method. As a result of solving the $N=7$ optimization problems of nonlinear mathematical programming by the FEA method, it was concluded that all the data of the seven boilers are effective $(h=1)$.

To rank this set of criteria by importance, MAI was used to determine the rating of boilers.

To compare the efficiency of the boilers that were investigated and determine the optimal indicators, a correlation and regression analysis of the reference table was carried out according to the Instruction [20] presented in Fig. 2 and data obtained by measuring (Fig. 3).
Having 19 pairs of data from the Instruction [20], let's establish the form of the connection between the data and build a correlation field (a dotted graph connected in descending order by straight lines) and obtain a regression line that can be described by a polynomial.

In this case, it is possible to see a simple dependency, which can be easily described by a function. In this case, the correlation coefficient for the field of values according to the Instructions: $r_{1}=0.99$. Thus, the theoretical indicator of the gross boiler efficiency depends on the quantitative change in the reference fuel consumption by $99 \%$.

Let's build a correlation field according to the measurements and calculations made on existing boilers (Table 3).

Tahle 3

Key estimates for the evaluation of the investigated boilers

\begin{tabular}{|c|c|c|c|}
\hline Boiler & $\begin{array}{c}\text { Efficiency, } \\
\text { direct } \\
\text { balance, } \\
\%\end{array}$ & $\begin{array}{c}\text { Fuel } \\
\text { utilization } \\
\text { factor, } \\
\mathrm{m}^{3} / \text { Gcal }\end{array}$ & $\begin{array}{c}\mathrm{CO}_{2}, \% \text { at } \\
\text { negative pres- } \\
\text { sure behind } \\
\text { the boiler } \\
\Delta P=3.5 \mathrm{~Pa} \text { at } \\
\text { nominal power }\end{array}$ \\
\hline $\begin{array}{l}\text { ATON } \\
\text { АОГВM-12 } \\
\text { EM }\end{array}$ & 88.31 & 162.36 & 3.3 \\
\hline $\begin{array}{l}\text { Д5 } \\
\text { LEMAK5 } \\
\text { Premium } \\
12.5\end{array}$ & 81.2 & 161.28 & 3.8 \\
\hline $\begin{array}{l}\text { ATEM «Zhy- } \\
\text { tomyг 3» } \\
\text { КСГ } 012 \\
\text { СН }\end{array}$ & 92.18 & 147.6 & 6.8 \\
\hline $\begin{array}{l}\text { Siberia } \\
2210-012 \\
\text { perf. } 3 \\
\text { Siberia } 11\end{array}$ & 86.7 & 159.69 & 3.6 \\
\hline $\begin{array}{l}\text { Danko } \\
\text { Danko-12СР }\end{array}$ & 86.3 & 154.8 & 1.9 \\
\hline $\begin{array}{l}\text { Termobar } \\
\text { КС-Г-12,5 }\end{array}$ & 88.2 & 164.88 & 3.1 \\
\hline $\begin{array}{l}\text { MIMAKS } \\
\text { КСГ-12,5 }\end{array}$ & 84.6 & 163.08 & 8.8 \\
\hline
\end{tabular}

Correlation coefficient for the field of values according to measurements and calculations of boiler efficiency and fuel consumption ratio: $r_{1}=-0.55$. At the same time, the inverse proportionality remains, but the dependence is only $55 \%$. This is significantly different from the data shown in Fig. 2. Thus, $45 \%$ has the influence of other factors on efficiency.

Let's conduct a correlation-regression analysis of fuel consumption and $\mathrm{CO}_{2}$ content (Fig. 4). As can be seen from Fig. 4, the most approximate to the ideal dependence of fuel consumption on the efficiency of boilers LEMAKS, MIMAKS and SIBERIA. The boilers of the trademarks ATON, DANKO, Termobar and ATEM fall out of the correlation field. 
The correlation coefficient for the field values of the fuel consumption ratio and $\mathrm{CO}_{2}$ content: $r_{1}=-0.14$. Thus, the relationship between these indicators is almost absent, while it makes it difficult to select such an approximating function, its value was quite close to the values according to measurements and calculations.

To obtain a generalized comprehensive assessment of the effectiveness of this work, the nonparametric method of multidimensional analysis is used, which combines the scoring method and the method of multidimensional comparisons. This method is quite simple to use, but at the same time, the estimates obtained as a result of its application adequately reflect the system of the study and provide useful and important information about the objects under study. The essence of the proposed methodology for integrated assessment of the effectiveness of boilers is in comparing the actual efficiencywith the benchmark indicators, and the efficiencyof the boilers having the worst values.

Approbation using the «3E» method provides a more realistic picture, which is based on three anchor efficiency indicators. So, on the basis of the adopted confidence intervals and the construction of a confidence field, it becomes possible to graphically display the rating of boilers (Fig. 5).

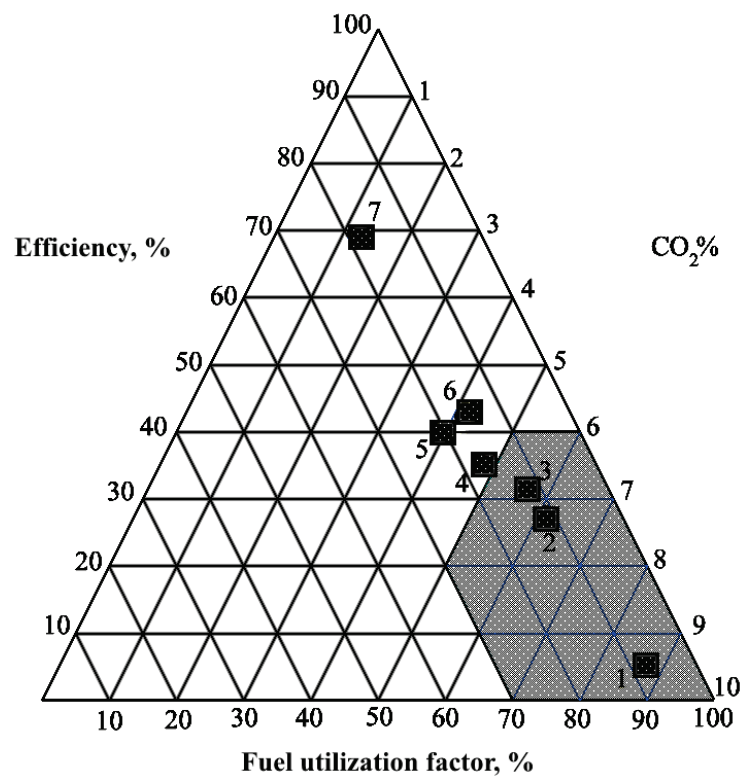

Fig. 5. «ZE» diagram of the boiler criteria for the evaluation of efficiency fuel utilization and carbon dioxide: 1 - ATEM; 2 - Termobar; 3 - ATON; 4 - Siberia; 5 - Lemaks; 6 - Danka; 7 - MIMAKS

Let's analyze the data using the author's multicriteria method «3E» to determine which of the analyzed boilers meet the specified criteria. To do this, within a triangle diagram, let's construct a field of confidence values, which is determined using the algorithm described in Section 5 and Table 2. Fig. 5 shows the result of the use of express analysis $\langle 3 \mathrm{E} »$, according to which in the field of confidence intervals there are three boiler units of manufacturers ATEM, Termobar and ATON. Thus, using a multi-criteria analysis, the optimal values of the indicators for each of the boilers were determined, and the affecting of the boiler units was carried out in a short time.

It is clearly seen that only three of the boilers, namely, boilers 1 - ATEM, 2 - Termobar, 3 - ATON, meet the standards of quality and efficiency, the worst indicators at the boiler 7 - MIMAKS, the other three boilers also do not meet modern requirements.

\section{SWOT analysis of research results}

Strengths. The «3E» method makes it possible to carry out multi-criteria analysis of complex systems and equipment with high accuracy, in a short time, usually impossible using standard statistical approaches and methods of mathematical modeling. Thus, this method is an important tool for energy management of enterprises for making strategic decisions.

Weaknesses. The result of the express analysis affects the exact construction of the boundaries of the confidence interval.

Opportunities. The proposed rapid analysis can be applied in other industries. Application of the $\ll 3 \mathrm{E} »$ method is completely independent of the sphere of activity in which the decision is made. The results of testing the $\ll 3 \mathrm{E} »$ method indicate the feasibility of its further use.

The variability and flexibility of this method is achieved by the ability to change the main criterion indicators, as well as the field of optimal values. In multi-criteria analysis, each of the efficiencycriteria acquires a specific quantitative value, which allows using the results of calculations in the decision-making process. Further development of the «3E» method requires testing at the enterprises of medium and large businesses, state institutions, in the defense industry in order to improve and unify the algorithms for creating the field of optimal values to make the right decision. This approach can be used as a marketing research tool for solving the problem of promoting a new product or service on the market and determining its competitiveness.

Threats. In some cases, with limited access to reliable information about the products of a production or service, an error may occur when determining the boundaries of the field of optimal values.

\section{Conclusions}

1. When conducting a technology audit based on field experiments and subsequent calculations using the method of reverse and direct balance, quantitative indicators of seven hot water WHGA-type boilers were found. According to them, a high energy indicator, namely, the efficiency of the direct balance of the ATEM boiler is $92.18 \%$, the lowest efficiency $=81.2 \%$ of the LEMAKS boiler, and the other five boilers also do not meet regulatory requirements. According to the economic criterion, namely the fuel utilization factor, the best indicator was obtained by the boiler company ATEM, CFU $=147.6 \mathrm{~m}^{3} / \mathrm{Gcal}$, the worst figure, by the same criterion, at the boiler of the company Termobar, $\mathrm{CFU}=164.88 \mathrm{~m}^{3} /$ Gcal. According to the environmental criterion, the best indicator is at the boiler of the MIMAKS company $\left(\mathrm{CO}_{2}=8.8 \%\right)$, the worst at the boiler of the Danko company $\left(\mathrm{CO}_{2}=1.9 \%\right)$. Based on this, the conclusion is drawn that a comparative analysis of efficiency requires additional research and the development of new methods of multi-criteria evaluation.

2. Analysis of the efficiency of boilers by the method of sums and the ranking of affects show that the boiler of ATEM is in the first place, the boilers of the firms LEMAKS and Siberia share fifth place. The correlationregressive method of comparing the indicators of efficiency, 
fuel consumption and $\mathrm{CO}_{2}$ content in flue gases shows that the boilers of the trademarks LEMAKS and MIMAKS are characterized by high fuel consumption and low efficiency. The best efficiency has a boiler company ATEM. The best environmental efficiency at nominal capacity in the boilers has ATEM and MIMAKS brandi, the worst in Danko, ATON and Termobar boilers. The results obtained by these two methods coincide with the results of the technology audit, therefore the complex relationship between efficiency indicators cannot be fully correctly determined using known methods of analysis. The results obtained by testing the $\ll 3 \mathrm{E} »$ method make it possible to obtain a more realistic and correct assessment of the effectiveness. The express method «3E» demonstrated that only boilers of the ATEM, Termobar and ATON trademarks meet all modern requirements for all efficiency criteria.

\section{References}

1. Demchenko V. G. Provedennia eksperymentalnykh teplo-ekolohichnykh vyprobuvan ta porivnialnykh rozrakhunkiv vodohriynykh kotliv, shcho pratsiuiut na hazovomu palyvi. 2018. URL: https://atem.ua/files/Reklama/ \%D0 \%9E \%D1 \%82 \%D1 \%87 \%D0 \%B5 \%D1 \%82 \%20 \%D0 \%9D \%D0 \%90 \%D0 \%9D $\% 20 \% \mathrm{D} 1 \% 83 \% \mathrm{D} 0 \% \mathrm{BA} \% \mathrm{\%} 1 \% 80 \% \mathrm{D} 0 \% \mathrm{~B} 0 \% \mathrm{D0} \% \mathrm{~B} 8$ $\%$ D0 \%BD \%D1 \%8B \%20 \%D0 \%BE \%20 \% $\%$ BE \%D1 \%82 \%D0 \%BB \%D0 \%B0 \%D1 \%85 \%200002.pdf

2. Teplovoy raschet kotel'nyh agregatov. Normativniy metod / Kuznecov N. V. et. al. 2-e izd., pererab. Moscow: Energiya, 1973. 296 p.

3. Metodicheskoe posobie po provedeniyu kompleksnyh ekologoteplotekhnicheskih ispytaniy kotlov, rabotayushchih na gaze i mazute / ed. by Sigal I. Ya. Kyiv, 1992. 213 p.

4. Trebovaniya po effektivnomu ispol'zovaniyu prirodnogo gaza i ohrane okruzhayushchey sredy pri provedenii naladochnyh rabot toplivoispol'zuyushchego oborudovaniya. Kyiv: Goskomneftegazprom, 1995

5. GDK 34.02.305-2002. Vikidi zabrudnyuyuchih rechovin v atmosferu vid energetichnih ustanovok. Metodika viznachennya. Kyiv, 2002.

6. Saaty T. L. Decision Making with Dependence and Feedback: The Analytic Network Process. Rws Publications, 2001. 370 p.

7. Belyaev I. P. Osnovy teorii prinyatiya resheniy. Moscow: MGSU, 2005. 275 p.

8. Andreychikov A. V., Andreychikova O. N. Analiz, sintez, planirovanie resheniy v ekonomike. Moscow: Finansy i statistika, 2004. 464 p.

9. Demchenko V. G. Bahatokryterialna otsinka zakhodiv po optymizatsiyi spozhyvannia teplovoi enerhiyi // Sbornik trudov XXVI mezhdunarodnoy konferencii «Problemy ekologii i ekspluatacii ob'ektov energetiki». Odessa, 2017. P. 53-56.

10. Saaty T. L. Relative measurement and its generalization in decision making why pairwise comparisons are central in mathematics for the measurement of intangible factors the analytic hierarchy/network process // Revista de la Real Academia de
Ciencias Exactas, Fisicas y Naturales. Serie A. Matematicas. 2008. Vol. 102, Issue 2. P. 251-318. doi: https://doi.org/10.1007/ bf03191825

11. Banker R. D., Charnes A., Cooper W. W. Some Models for Estimating Technical and Scale Inefficiencies in Data Envelopment Analysis // Management Science. 1984. Vol. 30, Issue 9. P. 1078-1092. doi: https://doi.org/10.1287/mnsc.30.9.1078

12. Cooper W. W., Seiford L. M., Tone K. Data Envelopment Analysis. A Comprehensive Text with Models, Applications, References and DEA-Solver Software. 2nd ed. Springer-Verlag, 2007. doi: https://doi.org/10.1007/978-0-387-45283-8

13. Drake P. R. Using the Analytic Hierarchy Process in Engineering Education // International Journal of Engineering Education. 1998. Vol. 14, Issue 3. P. 191-196.

14. Hallowell D. L. Analytical Hierarchy Process (AHP) - Getting Oriented. URL: https://www.isixsigma.com/tools-templates/ analytic-hierarchy-process-ahp/analytical-hierarchy-processahp- \%E2 \%90\%93-getting-oriented/

15. Saaty T. L. On the measurement of intangibles. A principal eigenvector approach to relative measurement derived from paired comparisons // Cloud of Science. 2015. Vol. 2, Issue 1.

16. Saaty T. L. Relative Measurement and Its Generalization in Decision Making. Why Pairwise Comparisons are Central in Mathematics for the Measurement of Intangible Factors // Cloud of Science. 2016. Vol. 3, Issue 2. P. 171-262. URL: https://cloudofscience.ru/sites/default/files/pdf/CoS_3_171.pdf

17. Demchenko V. G., Trubachev A. S. Ekspres-analiz dotsilnosti provedennia enerhozberihaiuchykh zakhodiv // The scientific method. 2018. Issue 20. P. 74-77.

18. Mobilni akumuliatory dlia dyskretnykh system teplokholodopostachannia. Chastyna 2 / Demchenko V. G. et. al. // Promyslova teplotekhnika. 2018. Vol. 40, Issue 3. P. 56-68.

19. Mezhotraslevye normy raskhodov topliva dlya otopitel'nyh kotlov, kotorye ekspluatiruyutsya v Ukraine: Prikaz Goskomenergosberezheniya No. 46 ot 7.05.2001.

20. Zvit pro postachannia teploenerhiyi: Instruktsiya shchodo zapovnennia formy derzhavnoho statystychnoho sposterezhennia $\mathrm{N}$ 1-tep. Zatverdzheno nakazom Derzhavnoho komitetu statystyky Ukrainy vid 17.08.2004. No. 482. Zareiestrovano v Ministerstvi yustytsiyi Ukrainy 31.08.2004 r. za No. 1079/9678.

Demchenko Volodymyr, PhD, Senior Researcher, Head of the Department of Processes and Technologies of Heat Supply, Institute of Engineering Thermophysics of National Academy of Sciences of Ukraine, Kyiv, Ukraine, e-mail: vptt@i.ua, ORCID: http://orcid.org/ 0000-0002-4211-356X

Trubachev Andrii, PhD, Senior Researcher, Department of Processes and Technologies of Heat Supply, Institute of Engineering Thermophysics of National Academy of Sciences of Ukraine, Kyiv, Ukraine, e-mail: astrubachev@gmail.com, ORCID: http://orcid.org/ 0000-0002-2903-2810

Hron Serhii, Engineer, Institute of Engineering Thermophysics of National Academy of Sciences of Ukraine, Kyiv, Ukraine, e-mail: sergey.gron2204@gmail.com, ORCID: http://orcid.org/0000-00029885-069X 